\title{
Nutrient Leaching in a Colombian Savanna Oxisol Amended with Biochar
}

\author{
Julie Major, Marco Rondon, Diego Molina, Susan J. Riha, and Johannes Lehmann*
}

Nutrient leaching in highly weathered tropical soils often poses a challenge for crop production. We investigated the effects of applying $20 \mathrm{t} \mathrm{ha}^{-1}$ biochar (BC) to a Colombian savanna Oxisol on soil hydrology and nutrient leaching in field experiments. Measurements were made over the third and fourth years after a single BC application. Nutrient contents in the soil solution were measured under one maize and one soybean crop each year that were routinely fertilized with mineral fertilizers. Leaching by unsaturated water flux was calculated using soil solution sampled with suction cup lysimeters and water flux estimates generated by the model HYDRUS 1-D. No significant difference $(p>0.05)$ was observed in surface-saturated hydraulic conductivity or soil water retention curves, resulting in no relevant changes in water percolation after BC additions in the studied soils. However, due to differences in soil solution concentrations, leaching of inorganic $\mathrm{N}, \mathrm{Ca}, \mathrm{Mg}$, and $\mathrm{K}$ measured up to a depth of $0.6 \mathrm{~m}$ increased $(p<0.05)$, whereas P leaching decreased, and leaching of all nutrients (except $\mathrm{P}$ ) at a depth of $1.2 \mathrm{~m}$ was significantly reduced with $\mathrm{BC}$ application. Changes in leaching at $2.0 \mathrm{~m}$ depth with $\mathrm{BC}$ additions were about one order of magnitude lower than at other depths, except for P. Biochar applications increased soil solution concentrations and downward movement of nutrients in the root zone and decreased leaching of $\mathrm{Ca}, \mathrm{Mg}$, and $\mathrm{Sr}$ at $1.2 \mathrm{~m}$, possibly by a combination of retention and crop nutrient uptake.

Copyright $\odot 2012$ by the American Society of Agronomy, Crop Science Society of America, and Soil Science Society of America. All rights reserved. No part of this periodical may be reproduced or transmitted in any form or by any means, electronic or mechanical, including photocopying, recording, or any information storage and retrieval system, without permission in writing from the publisher.

J. Environ. Qual. 41

doi:10.2134/jeq2011.0128

Supplemental data file is available online for this article.

Received 5 Apr. 2011.

*Corresponding author (CL273@cornell.edu).

๑ $\mathrm{ASA}$, CSSA, SSSA

5585 Guilford Rd., Madison, WI 53711 USA
U NDERSTANDING WATER FLUX through soil is important for crop as well as environmental management. Water can carry agricultural chemicals and nutrients away from plant root zones and into aquifers. The quantity and mechanism of drainage have significance for crop water and nutrition management. A large proportion of applied as well as intrinsic soil nutrients can be leached below the plant root zone (Cahn et al., 1993; Melgar et al., 1992; Omoti et al., 1983; Randall et al., 1997). This can occur very rapidly in well aggregated clayey soils (Renck and Lehmann, 2004).

Biochar (BC) (biomass-derived black carbon or charcoal) addition to soil has been shown to improve crop yields (Lehmann et al., 2003; Rondon et al., 2007; Steiner et al., 2007; Blackwell et al., 2009; Major et al., 2010b), but its effect on soil hydrology and nutrient leaching has received less attention. Increased biomass production due to $\mathrm{BC}$ application to soil implies greater plant water uptake. It follows that in BC-amended soil, more water may be lost to evapotranspiration. Less water would then move through the soil by unsaturated flux in response to differences in matric potential.

Biochar materials are highly porous (Downie et al., 2009) and have a low density compared with soil. Biochar develops negatively charged surfaces as weathering occurs (Cheng et al., 2006, 2008; Liang et al., 2006) and consequently forms interactions with soil minerals (Glaser et al., 2000). Also, BC has been demonstrated to sorb a variety of molecules in soil, including pesticides (Yu et al., 2006), simple hydrophobic organic molecules (Smernik, 2005), and plant leaf extracts (Pietikäinen et al., 2000). Soil-applied BC likely favors the growth of microorganisms (Warnock et al., 2007), which, combined with interactions with minerals and other soil organic matter, may lead to greater soil aggregation. These changes may result in different water flow characteristics after BC additions to soil.

Tryon (1948) reported that the water holding capacity of a sandy soil was improved by $\mathrm{BC}$ addition in the laboratory, whereas $\mathrm{BC}$ addition to a loam had no effect and $\mathrm{BC}$ addition to a clay soil reduced water holding capacity. All trends increased or decreased linearly with increasing BC addition

\footnotetext{
J. Major and J. Lehmann, Dep. of Crop and Soil Sciences, Cornell Univ., Ithaca, NY 14853; M. Rondon and D. Molina, Centro Internacional de Agricultura Tropical (CIAT), A.A. 6713 Cali, Colombia; S.J. Riha, Dep. of Earth and Atmospheric Sciences, Cornell Univ., Ithaca, NY 14853; J. Major, current address: Faculty of Agricultural and Environmental Sciences, McGill Univ., 21,1111 Lakeshore, Ste-Anne-deBellevue, QC H9X 3V9, Canada; M. Rondon, current address: International Development Research Centre, Ottawa, ON K1G 3H9, Canada; D. Molina, current address: Centro de Investigaciones en Palma de Aceite, cra 42 \# 33-07 Villavicencio, Colombia. Assigned to Associate Editor James Ippolito.
} 
rates. Ayodele et al. (2009) reported increased infiltration and lower runoff in soils of old charcoal storage sites in Ghana.

Major et al. (2009) suggested several hypotheses for mechanisms through which BC could decrease and increase nutrient leaching after application to soil. For example, greater cation exchange capacity with $\mathrm{BC}$ could improve the retention of inorganic forms of nutrients on BC surfaces. Alternatively, leaching could be promoted through facilitated transport of nutrients sorbed to BC particles or through improved saturated flux in soil due to increased soil aggregation with $\mathrm{BC}$. Also, improved crop production with $\mathrm{BC}$ in itself can reduce nutrient leaching indirectly through greater nutrient and water uptake. The relative importance of these proposed mechanisms is not clear.

If $\mathrm{BC}$ retains more nutrients, their loss through leaching could be reduced. This process for increasing nutrient availability has been shown in laboratory (Dünisch et al., 2007; Novak et al., 2009a; Laird et al., 2010b; Singh et al., 2010) and greenhouse studies with plants (Lehmann et al., 2003; Knowles et al., 2011). Lehmann et al. (2003) found that "fresh" BC addition to a tropical Oxisol led to a $60 \%$ reduction in leaching of applied ammonium $\left(\mathrm{NH}_{4}^{+}\right)$compared with the unamended control over $40 \mathrm{~d}$ of cropping rice (Oryza sativa L.). Calcium (Ca) and magnesium ( $\mathrm{Mg}$ ) leaching was also reduced early on in the trial, but potassium $(\mathrm{K})$ leaching was not, presumably because the $\mathrm{BC}$ material used contained large amounts of K (Lehmann et al., 2003; Laird et al., 2010b). Novak et al. (2009a) also found reductions in leaching of $\mathrm{Ca}, \mathrm{Mg}, \mathrm{Mn}$, $\mathrm{P}$, and $\mathrm{Zn}$ when $\mathrm{BC}$ was applied to an Ultisol, with leaching reductions being more prominent after $25 \mathrm{~d}$ than after $67 \mathrm{~d}$ of incubation. However, leaching of $\mathrm{K}$ and $\mathrm{Na}$ generally increased with greater BC application rates. The authors suggested retention of divalent cations and phosphate on BC surfaces as a mechanism underlying the observed leaching reductions. Singh et al. (2010) found greater ammonium retention over monthly time periods, which suggests development of cation exchange sites through oxidation. In a field experiment, a greater proportion of isotopically labeled nitrogen $(\mathrm{N})$ was retained in an Oxisol cropped to Sorghum sp. in the Brazilian Amazon for $2 \mathrm{yr}$ after BC was added compared with compost, although leaching was not measured directly (Steiner et al., 2007, 2008). We are unaware of any published work directly assessing the effect of BC application on soil hydrology and nutrient leaching in the field over several cropping seasons.

This work was undertaken to investigate the effects of BC on soil physical properties, water movement, and nutrient leaching by unsaturated flux through a heavy clay soil over multiple cropping seasons.

\section{Materials and Methods Field Plot Establishment}

Field work took place on a Typic Haplustox clay soil (Soil Survey Staff, 1994) at the Matazul farm $\left(04^{\circ} 10^{\prime} 15.2^{\prime \prime} \mathrm{N}\right.$, $\left.072^{\circ} 36^{\prime} 12.9^{\prime \prime} \mathrm{W}\right)$ in Colombia's nonflooded oriental savanna region. The soils are acid with a $\mathrm{pH}(\mathrm{KCl})$ of $3.87,40$ to $44 \%$ clay, relatively low in organic $\mathrm{C}\left(20.1 \mathrm{~g} \mathrm{~kg}^{-1}\right)$, and a total $\mathrm{N}$ concentration of $1.3 \mathrm{~g} \mathrm{~kg}^{-1}$ at 0 to $0.1 \mathrm{~m}$ (full details are provided in Major et al., 2010b). The prevailing slope at the experimen- tal location was estimated at approximately 3\%. Long-term average annual rainfall measured at a research station approximately $200 \mathrm{~km}$ northeast of the research plot is $2200 \mathrm{~mm}$, and average annual temperature is $26^{\circ} \mathrm{C}$ (Rippstein et al., 2001). A marked dry season occurs between January and March.

In December 2002, native savanna grasses were chisel plowed, and dolomite was applied at $2.2 \mathrm{t} \mathrm{ha}^{-1}$ and incorporated to $0.30 \mathrm{~m}$, using two passes of a chisel plow. Biochar (Table 1) was applied $9 \mathrm{~d}$ later in a randomized, complete block design with three replicates. Plots measuring 4 by $5 \mathrm{~m}$ were separated by $1 \mathrm{~m}$ within blocks between replicates and by $2 \mathrm{~m}$ between blocks (Fig. 1).

The BC used was produced commercially for cooking from a variety of wood species that were available locally using a traditional mound kiln (Brown, 2009). The charring for mound kilns typically takes several days and reaches temperatures about 500 to $700^{\circ} \mathrm{C}(\mathrm{FAO}, 1983)$. Methods for BC analysis are described elsewhere (Major et al., 2010b), and analytical results are shown in Table 1. The BC was ground using a tractor and a roller to pass through a 5-mm mesh. No further dolomite or BC applications occurred during the trial period. Biochar was applied by hand using rakes and incorporated shortly after application with one pass of a disc harrow to a depth of $50 \mathrm{~mm}$. Application rates were 0,8 , and $20 \mathrm{tha}^{-1}$, in three replicates each. Only the 0 and $20 \mathrm{t} \mathrm{ha}^{-1}$ application rates are discussed here.

From May 2003 to December 2006, a maize (Zea mays L.)-soybean [Glycine $\max (\mathrm{L}$.$) Merr.] rotation was grown on$ the plots. Row spacing was $0.8 \mathrm{~m}$ for maize and $0.4 \mathrm{~m}$ for soybean. Although the spacing was reduced for soybean, in the rows where sampling equipment was installed the spacing of $0.8 \mathrm{~m}$ was maintained and was identical between the treatments with and without $\mathrm{BC}$ additions. Hydrological monitoring and soil solution sampling were performed between April 2005 and December 2006 over two growing seasons and four crops. Throughout this report, time is

Table 1. Properties of wood biochar made commercially for cooking and applied to a Colombian savanna Oxisol in 2002.

\begin{tabular}{lc}
\hline \multicolumn{1}{c}{ Property } & Biochar \\
\hline $\mathrm{pH}, \mathrm{H}_{2} \mathrm{O}$ & $9.20 \dagger$ \\
$\mathrm{pH}, \mathrm{KCl}$ & 7.17 \\
Total C, \% & 72.9 \\
Total N, \% & 0.76 \\
$\mathrm{C} / \mathrm{N} \neq$ & 121 \\
$\mathrm{H} / \mathrm{C} \neq$ & 0.21 \\
$\mathrm{O} / \mathrm{C} \neq$ & 0.19 \\
$\mathrm{Ash}, \%$ & 4.6 \\
$\mathrm{Ca}, \S \mu \mathrm{g} \mathrm{g}^{-1}$ & 330.7 \\
$\mathrm{Mg}, \S \mu \mathrm{g} \mathrm{g}^{-1}$ & 48.9 \\
$\mathrm{P}, \S \mu \mathrm{g} \mathrm{g}^{-1}$ & 29.8 \\
$\mathrm{~K}, \S \mu \mathrm{g} \mathrm{g}^{-1}$ & 463.8 \\
$\mathrm{Sr}, \S \mu \mathrm{g} \mathrm{g}^{-1}$ & 2.6 \\
$\mathrm{CEC}, \mathbf{9} \mathrm{mmol}_{c} \mathrm{~kg}^{-1}$ & 111.9 \\
\hline
\end{tabular}

+ Values shown are averages of two analytical replicates (data from Major et al. [2010b]).

₹ Ratios calculated on a molar basis.

$\S$ Available nutrients extracted with Mehlich III (Mehlich, 1984) and quantified by inductively coupled atomic emission spectroscopy.

I Cation exchange capacity. 
shown as consecutively numbered days, where Day 1 is 5 May 2005 and the last day, Day 595, is 20 Dec. 2006. No tillage was performed after BC application, which occurred 2 yr before this work started. At planting, crop seeds and fertilizer were banded into open furrows using hand tools. Fertilizer was side-dressed at the surface after crop establishment. Synthetic fertilizers were applied with each crop, and pest management was performed when necessary using pesticides (further details are provided in Major et al., 2010b).

\section{Soil Sampling and Measurements}

Soil was sampled on 25 and 26 Apr. 2006 to a depth of $2.0 \mathrm{~m}$ using a core auger ( $\sim 20 \mathrm{~mm}$ diameter). Depth increments were 0 to $0.15,0.15$ to $0.3,0.3$ to $0.6,0.6$ to 1.2 , and 1.2 to $2.0 \mathrm{~m}$. In each plot, 10 points were sampled for depth increments 0 to $0.15 \mathrm{~m}$ and 0.15 to 0.3 $\mathrm{m}$, five points were sampled for depth increment 0.3 to $0.6 \mathrm{~m}$, and two points were sampled for increments 0.6 to 1.2 and 1.2 to $2.0 \mathrm{~m}$. Within each plot, soil from each depth increment was pooled, homogenized, and subsampled. Air-dried soil was crushed and sieved and used for particle size analysis using the hydrometer method (Gee and Bauder, 1986). Soil $\mathrm{pH}$ was measured in a 1:2.5 w/v soil/deionized water mixture, agitated three times over the course of $1 \mathrm{~h}$, and measured using a gel electrode (Symphony; VWR, West Chester, PA).

In July 2006, additional soil samples were taken to analyze soil physical properties. A small pit was dug to $0.3 \mathrm{~m}$ in each plot. Intact soil cores in aluminum rings were taken at the surface and at depths of 0.15 and $0.3 \mathrm{~m}$. Paired samples were taken at each depth from each side of the pit. One core was $25 \mathrm{~mm}$ high, and one was $50 \mathrm{~mm}$ high (both with $50 \mathrm{~mm}$ diam.). Six samples per depth per treatment were obtained. A total of 36 samples of each size were collected. Because Major et al. (2010a) observed no change in $\mathrm{C}$ content or isotopic signature derived from the applied BC below $0.3 \mathrm{~m}$ depth in BC-amended plots of a nearby experiment on sandier soil, indicating no significant transport of BC into the subsoil, we assumed no effect of BC application on physical properties for depths of $0.6,1.2$, and $2.0 \mathrm{~m}$. To characterize soil physical properties at these depths, two soil pits located directly adjacent to the experimental plots were used. It is very unlikely that physical differences in the soil at these depths would show important variation over a distance of only a few meters, and it was not possible to dig pits inside the experimental area that would be large enough to obtain intact soil core samples. Two depth profiles were sampled in each pit, on the side adjacent to the experiment. This yielded a total of four samples from each depth. Bulk density was measured with two of the rings having a height of $50 \mathrm{~mm}$ and a diameter of $50 \mathrm{~mm}$ by weighing after oven drying at $105^{\circ} \mathrm{C}$ to constant
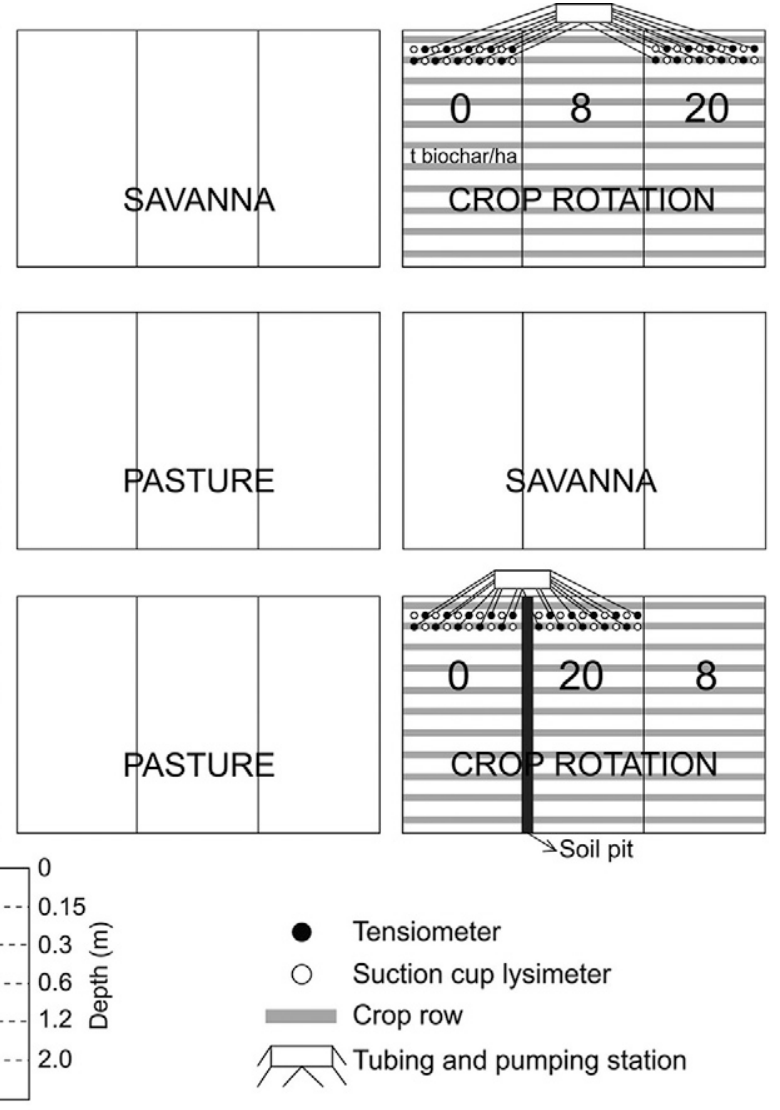

Soil pit wall
0.15

$0.3 \widehat{E}$

0.6 흥

2.0

Tubing and pumping station

t study, only plots cropped to maize receiving Fig. 1. Diagram of the field plot layout. In the
biochar at a rate of $20 \mathrm{t} \mathrm{ha}^{-1}$ were included.

weight. Smaller rings (two per depth) with a height of $25 \mathrm{~mm}$ and a diameter of $50 \mathrm{~mm}$ were used to determine the moisture retention curve using a pressure plate extractor (SoilMoisture Equipment Corp., Santa Barbara CA).

On 16 May, 21 Sept., and 20 Dec. 2006, surface infiltration rates were measured using a constant head disk infiltrometer with a Mariotte device (Ayodele et al., 2009). In September 2006, infiltration rates were also recorded using a double-ring infiltrometer with a changing pressure head to allow for a comparison of saturated conductivity at larger scale (Boxell and Drohan, 2009). Details on the infiltration measurements are provided in the online supplement.

\section{Maize Rooting}

To parameterize the water flux model, maize rooting was estimated during grain filling in July 2006, using an auger with a diameter of $50 \mathrm{~mm}$. Five profiles were sampled on a transect in each maize plot: one on a crop row, one on either side of this row at a distance of $0.1 \mathrm{~m}$, and one on either side of the row at a distance of $0.2 \mathrm{~m}$. Depth increments were 0 to $0.2,0.2$ to 0.4 , and 0.4 to $0.6 \mathrm{~m}$. Samples were pooled by depth for each plot, and soil was washed from roots with water. Roots that were visually deemed to be alive were then dried at $65^{\circ} \mathrm{C}$ to constant weight, and the weights were recorded.

\section{Soil Water Potential Measurement}

Tensiometers were used to measure soil water potential and were constructed from PVC piping glued to ceramic cups with 
a 1-bar air entry potential (Soil Moisture Equipment Corp., Santa Barbara, CA). The top ends of pipes were extended by a transparent acrylic tube. Ceramic cups were glued using pavement epoxy glue (Adhesivo epóxico Polarix; E\&M, Bogotá, Colombia), which remained flexible while maintaining vacuum. In each plot receiving 0 or $20 \mathrm{t} \mathrm{BC} \mathrm{ha}{ }^{-1}$, two tensiometers were inserted vertically into the soil, each to depths of $0.15,0.3,0.6,1.2$, and $2.0 \mathrm{~m}$, for a total of six tensiometers per depth and per treatment. Tensiometers were installed in December 2004 and allowed to equilibrate with the soil until measurements began in May 2005. Possible preferential flow along the tubes was minimized by tightly fitting $50 \times 50 \mathrm{~mm}$ pieces of thick vinyl floor covering and placed around the shafts at the soil surface. Tensiometers were interspersed with an equal number of suction cup lysimeters (described below) used to sample the soil solution, and all equipment was located on two lines, one falling within a crop row and one falling between two crop rows of each replicated plot (Fig. 1). On each line, the units were allocated using two sets of randomly generated designs, which ensured that no two units of equal depth were directly next to each other.

Tensiometer shafts were filled with de-aired water and sealed with rubber septa. Tensiometers were refilled on the day before readings were taken. Vacuum in the air pocket was measured by puncturing the rubber septa with a needle connected to a hand-held vacuum gauge with a $-1 \mathrm{hPa}$ resolution and digital display that allowed measurements well above the airentry point of the suction cups (TensioCheck TC 03S; Tensio Technik, Geisenheim, Germany). Matric potential was measured between 0700 and noon, daily from May to November 2005, and weekly during December 2005 and from 28 Mar. to 13 Dec. 2006. During the dry season, which occurs yearly from January to March, the soil matric potential was too low to be measured using tensiometers.

\section{Suction Cup Lysimeters}

The plots that received 0 and $20 \mathrm{t} \mathrm{BC} \mathrm{ha}{ }^{-1}$ were equipped with suction cup lysimeters constructed from ceramic cups with a 1-bar air entry potential (Soil Moisture Equipment Corp.) glued to PVC pipes using pavement epoxy glue as described above. Capillary polyethylene tubing was placed to touch the bottom of each cup. The mouths of the cups were sealed around the tubing using silicon adhesive, with the capillary tubing emerging from the PVC tubes. Twelve suction cups (i.e., two per replicate plot) were inserted at the same time and depths as the tensiometers using a similar placement procedure. Preferential flow was also controlled as described above.

The capillary tubing originating from each ceramic cup was fitted through rubber stoppers and into dark green glass collection bottles that had been washed with dilute $\mathrm{HCl}$ and $\mathrm{NaOH}$, with each bottle collecting water from the two lysimeters present at a given depth in the replicate plot (i.e., one within and one between crop rows). Vacuum was applied uniformly to all collection bottles by three $12 \mathrm{~V}$ battery-operated pumps (Gast Manufacturing Inc., Benton Harbor, MI) regulated by vacuum switches (Square-D, Rueil-Malmaison, France) (one set per replicate plot; Fig. 1).

On 3 June 2005, after 2 wk of flushing the system at high vacuum, switches were set to turn pumps on when potential in the collection vessels dropped below $-135 \mathrm{hPa}$ and off when potential reached $-200 \mathrm{hPa}$. During the last $2 \mathrm{wk}$ of the 2005 growing season, when rains had stopped and the soil was drying, switch settings were increased to -200 and $-270 \mathrm{hPa}$, respectively. Sampling ended on 27 Dec. 2005, when the soil was very dry. In 2006, switch settings were again set at -135 and $-200 \mathrm{hPa}$ starting $27 \mathrm{March}$ and at -200 and $-270 \mathrm{hPa}$ starting 3 August. The last sampling date was 14 Dec. 2006, at soybean harvest.

Collection bottles were emptied weekly. Soil solution subsamples were stored at 4 or $-20^{\circ} \mathrm{C}$ in plastic bottles until being shipped to the laboratory by courier within 2 mo and then kept between -20 and $2^{\circ} \mathrm{C}$ until analysis. To prevent biological activity in the sample bottles, a solution of $\mathrm{HgCl}_{2}$ was added as a biocide to achieve a final concentration of $30 \mu \mathrm{M}$ in a $500-\mathrm{mL}$ sample. The water samples collected were analyzed for nutrients (Table 2) and strontium (Sr), which is a common contaminant in fertilizers (Senesi et al., 2005) and behaves in soil and is taken up by plants similarly to Ca (Aberg, 1995). Phosphorus, Ca, $\mathrm{Mg}, \mathrm{K}$, and $\mathrm{Sr}$ were analyzed by atomic emission spectrometry (Trace Analyzer; Thermo Jarrell Ash, Franklin, MA), nitrate using an ion chromatograph (model ICS 2000; Dionex Corp., Bannockburn, IL), ammonium colorimetrically by the phenate method (method 4500- $\mathrm{NH}_{3} \mathrm{~F}$ in Clescerl et al., 1999), and $\mathrm{pH}$ using a gel electrode (Symphony; VWR).

Table 2. Nutrient concentrations in leached water from suction cups $(n=189)$ over the 2005 and 2006 rainy seasons under a Colombian savanna Oxisol that received 0 or $20 \mathrm{tha}^{-1}$ biochar in 2002.

\begin{tabular}{|c|c|c|c|c|c|c|c|c|}
\hline \multirow{2}{*}{ Depth } & \multirow{2}{*}{ Biochar } & \multicolumn{7}{|c|}{ Concentration in soil solution } \\
\hline & & $\mathbf{P}$ & $\mathrm{Sr}$ & $\mathrm{NH}_{4}-\mathrm{N}$ & $\mathrm{NO}_{3}-\mathrm{N}$ & $\mathrm{Ca}$ & $\mathrm{Mg}$ & $\mathrm{K}$ \\
\hline $\mathrm{m}$ & $\mathrm{tha}^{-1}$ & - & - & 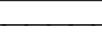 & $-\mathrm{mg} \mathrm{L}^{-1}-$ & 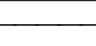 & & - \\
\hline \multirow[t]{2}{*}{0.15} & 0 & 0.02 & $0.01 b$ & 0.39 & 5.59 & $2.23 \mathrm{~b} \dagger$ & $0.68 b$ & $7.43 b$ \\
\hline & 20 & 0.02 & $0.03 a$ & 1.97 & 9.05 & 7.33a & $4.22 \mathrm{a}$ & $13.94 a$ \\
\hline \multirow[t]{2}{*}{0.3} & 0 & 0.02 & $0.02 \mathrm{~b}$ & 0.08 & $7.51 b$ & $4.13 b$ & 2.68 & 6.69 \\
\hline & 20 & 0.02 & $0.03 a$ & 0.07 & $10.30 a$ & $5.76 a$ & 2.92 & 6.22 \\
\hline \multirow[t]{2}{*}{0.6} & 0 & 0.02 & $0.01 b$ & $0.03 b$ & $7.17 \mathrm{~b}$ & $3.06 \mathrm{~b}$ & $2.00 \mathrm{~b}$ & $4.62 \mathrm{~b}$ \\
\hline & 20 & 0.02 & $0.04 a$ & $0.09 a$ & 14.97a & $8.10 a$ & $4.19 a$ & $5.82 \mathrm{a}$ \\
\hline \multirow[t]{2}{*}{1.2} & 0 & 0.02 & $0.02 a$ & 0.04 & $5.09 a$ & 2.43a & $1.51 \mathrm{a}$ & $1.86 a$ \\
\hline & 20 & 0.02 & $0.01 b$ & 0.07 & $4.68 \mathrm{~b}$ & $1.99 b$ & $1.13 b$ & $1.13 b$ \\
\hline \multirow[t]{2}{*}{2.0} & 0 & $0.02 \mathrm{a}$ & $0.003 b$ & $0.03 a$ & 0.53 & 0.29 & 0.13 & $0.70 a$ \\
\hline & 20 & $0.01 \mathrm{~b}$ & $0.004 a$ & $0.02 \mathrm{~b}$ & 0.88 & 0.39 & 0.19 & $0.66 \mathrm{~b}$ \\
\hline
\end{tabular}

† Different letters represent significant differences $(p<0.05 ; n=3)$ between treatments at a single depth. 
Typically, suction lysimeters do not efficiently capture saturated flux (Renck and Lehmann, 2004) because they do not sample free-draining pores (van der Ploeg and Beese, 1977). Therefore, we refer to data obtained from the suction cups and modeling as relating to mainly unsaturated flux, although it cannot be ruled out that water moving by saturated flux was sampled to some degree by suction cup lysimeters.

\section{Logged Soil Water Measurements}

For obtaining soil water potential with high temporal resolution to capture rapid water flow (Renck and Lehmann, 2004), datalogged tensiometers were inserted from the walls of a 2-mdeep, plastic-lined soil pit giving access to the 0 and $20 \mathrm{t} \mathrm{ha}^{-1}$ $\mathrm{BC}$ plots of one of the replicates. Tensiometer shafts measured $0.3 \mathrm{~m}$, and these were inserted at a $30^{\circ}$ angle from horizontal such that the ceramic cups rested at depths of $0.15,0.3,0.6,1.2$, and $2.0 \mathrm{~m}$, with one tensiometer per depth per treatment. De-aired water was used to fill tensiometers, and these were fitted with pressure transducers (model SWT3; UMS, Munich, Germany) (range +1000 to $-1600 \mathrm{hPa}, \pm 2 \mathrm{hPa}$ ) connected to a data logger (model DL2e; Delta-T Devices, Cambridge, UK). Soil matric potential was measured every 10 min during the 2005 and 2006 rainy seasons, and the tensiometers were refilled at least weekly with de-aired water. Frequency domain reflectometry soil moisture probes (Theta probe ML2; Delta-T Devices) were inserted from pit walls on $28 \mathrm{Apr} .2006$ at depths of 0.15 and $0.3 \mathrm{~m}$, with one probe in each treatment and at each of these depths. Data from these probes were logged as above.

\section{Meteorological Data}

In December 2004, a tipping bucket rain gauge (Rain-O-Matic; Pronamic, Silkeborg, Denmark) (1 mm per tipping) connected to an event logger (HOBO Event; Onset Computer Corp., Bourne, MA) was installed in a corner of the experimental area. A weather station (HOBO MicroStation; Onset Computer Corp.) was installed in March 2006 along an edge of the experimental area. Every $10 \mathrm{~min}$, rainfall was logged using a tipping bucket rain gauge ( $0.2 \mathrm{~mm}$ per tipping), global solar radiation was logged using a silicon pyranometer, and temperature was logged using a platinum resistance temperature detector (all by Onset Computer Corp.). Relative humidity was logged using a capacitive RH chip (model CS500; Campbell Scientific, Logan, UT) connected to the DL2e data logger. For the year 2005, weather data (except for rain) needed for water modeling were obtained from Colombia's Institute for Hydrology, Meteorology and Environmental Studies (IDEAM) for a station located approximately $52 \mathrm{~km}$ northeast of the experimental plots. Data collected in 2006 at this station were also obtained and used to check correlation with measured data at the experiment location. Correlation coefficients were high for global radiation (0.70) and average daily relative humidity (0.54) and lower for daily minimum temperature $(0.38)$ because the amplitude of temperature variation was only $6^{\circ} \mathrm{C}$ for the study period. Total rainfall measured at the experimental location was $1848 \mathrm{~mm}$ (17 May to 31 Dec. 2005) and $2314 \mathrm{~mm}$ (28 Mar. to 17 Dec. 2006). Detailed rainfall dynamics are shown in Fig. 2. Average maximum temperatures were 31.3 and $31.4^{\circ} \mathrm{C}$, and average minimum temperatures were 22.2 and $22.0^{\circ} \mathrm{C}$ for these time periods in 2005 and 2006, respectively.

\section{Modeling}

Water flux was estimated using the one-dimensional, finite element HYDRUS 1D model v. 4.05 (Šimůnek et al., 2008), which numerically solves the Richards equation (Richards, 1931) for variably unsaturated flux. Water flux through the entire profile was modeled simultaneously. Potential evapotranspiration (ET) estimates were generated for input into HYDRUS using weather data obtained from the weather station or from IDEAM and using the software application RefET (Allen, 2001). Output from the software generated with the Priestley-Taylor equation (Priestley and Taylor, 1972) was partitioned into evaporation $\left(\mathrm{E}, \mathrm{cm} \mathrm{d}^{-1}\right)$ and transpiration $\left(\mathrm{T}, \mathrm{cm} \mathrm{d}^{-1}\right)$ using the following equations (Ritchie, 1972):

$\mathrm{E}=(1-\mathrm{SCF})^{*} \mathrm{ET}$

$\mathrm{T}=\mathrm{SCF} * \mathrm{ET}$

where SCF is soil cover fraction:

$\mathrm{SCF}=1-\mathrm{e}^{\left(-a^{*} \mathrm{LAI}\right)}$

where the radiation extinction of the canopy, $a$, is 0.463 , and LAI is leaf area index.

Leaf area index data reported for tropical America were used from Sierra et al. (2003) for maize and from Sinclair et al. (2003) for soybean. HYDRUS was run four times, once for each treatment and year. Inverse modeling solutions were used in each run, with an input of datalogged and hand-read tensiometer data used to optimize measured soil hydrological parameters. The model likely underestimates saturated flux because water flow in large pores is typically not captured (Beven and Germann, 1982) and calculations do not account for bimodal pore distribution common in aggregated tropical Oxisols (Tomasella and Hodnett, 1998). We used model output multiplied by nutrient concentrations sampled by suction cup lysimeters to calculate leaching dominated by unsaturated flux.

\section{Statistical Analyses}

Statistical differences between treatment means were determined using PROC GLM in SAS (SAS Institute, 2003), and differences were deemed to be significant when $p<0.05$. For measurements taken repeatedly over time, measurement days were treated as replicates, and time was not included as a predictor in the model. After verifying diagnostic residual plots from nutrient movement dominated by unsaturated flux, data were log-transformed to comply with the model's assumption of equal variance.

\section{Results \\ Soil Characteristics}

The particle size distribution in the top $2 \mathrm{~m}$ of the soil was not affected by the application of $20 \mathrm{tha}^{-1} \mathrm{BC}(p>0.05)$ (Table 3$)$. Significant differences $(p<0.05)$ in bulk density were found only at $0.15 \mathrm{~m}$, where the density of unamended control soil $\left(1.22 \mathrm{~g} \mathrm{~cm}^{-3}\right)$ was greater than that of $\mathrm{BC}$-amended soil $\left(1.11 \mathrm{~g} \mathrm{~cm}^{-3}\right)$ (Table 3). The moisture retention data at the surface and at the 0.15 and $0.3 \mathrm{~m}$ depths were also unaffected 

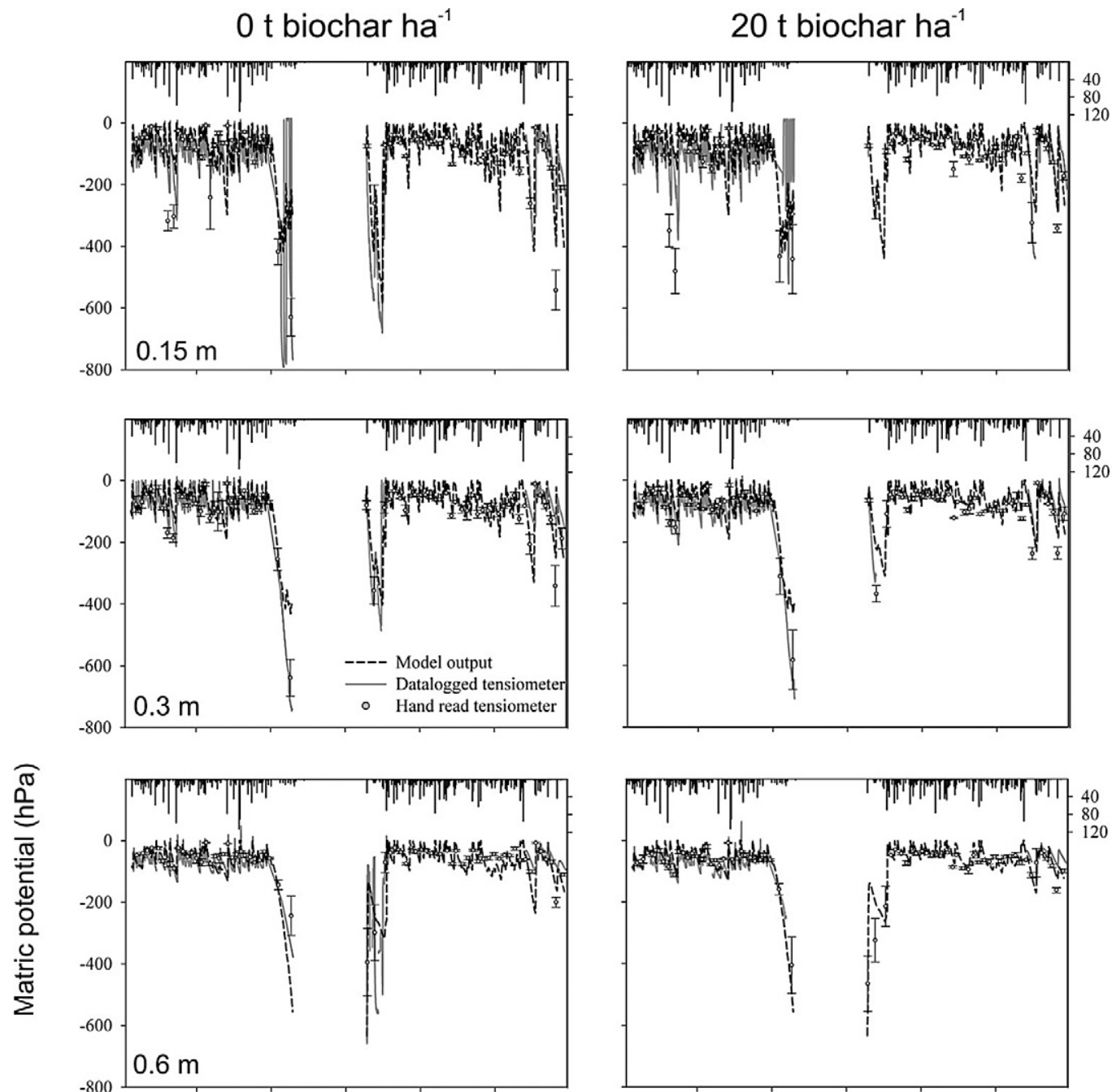

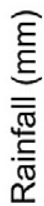
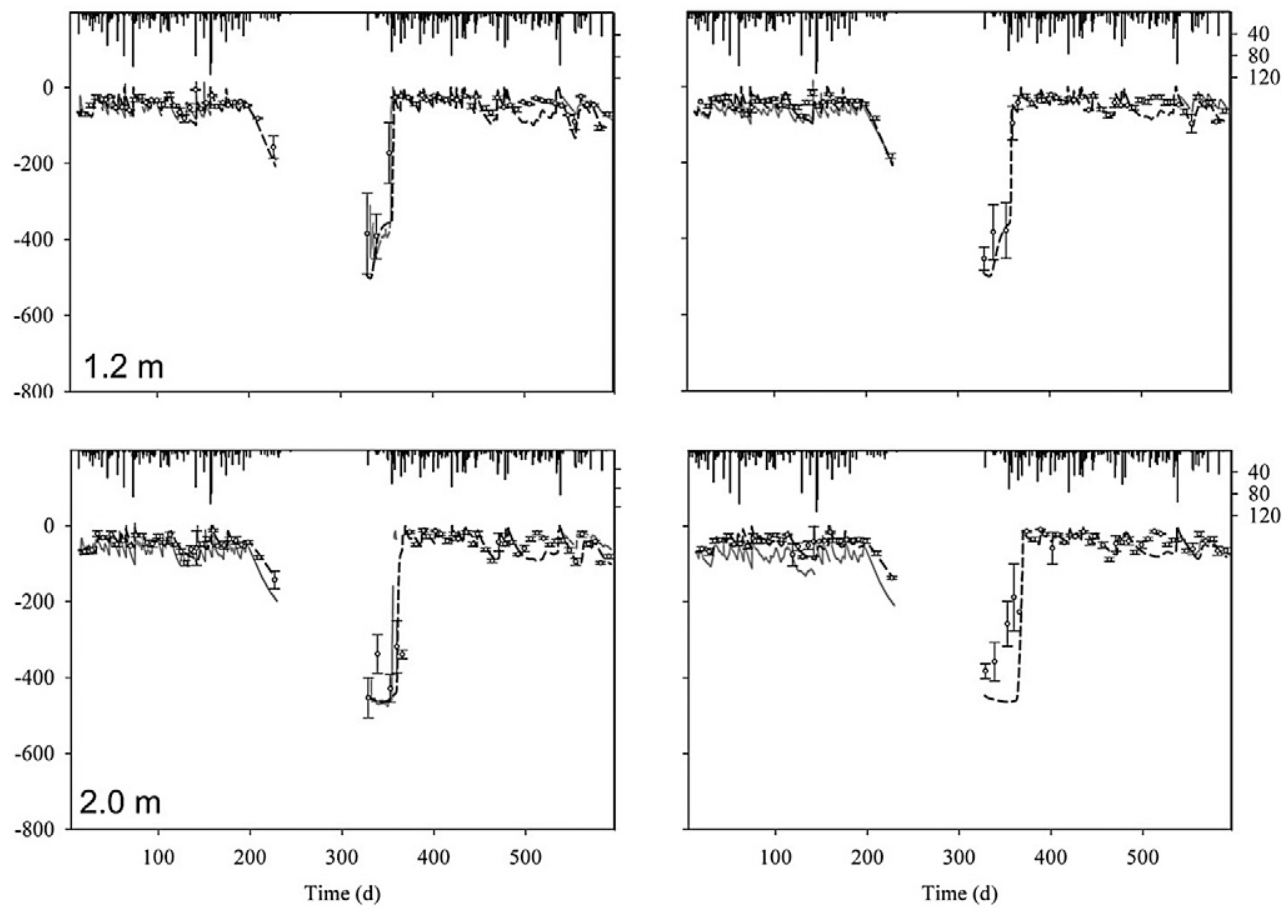

Fig. 2. Soil matric potential measured over two rainy seasons with datalogged and hand-read tensiometers as well as predicted by the HYDRUS model on control and biochar-amended plots on a Colombian savanna Oxisol. Daily rainfall shown with bars on right axis. 
by BC application $(p>0.05)$ (Supplemental Fig. S1). Similarly, surface-saturated hydraulic conductivity data measured using the disk infiltrometer or the double-ring infiltrometer were not statistically different between soil with and without BC additions ( $p>0.05)$ (Supplemental Fig. S2). Biochar application did not affect root density to the maximum measurement depth of $0.6 \mathrm{~m}(p>0.05)$ (Table 3).

\section{Soil Water Potential and Water Content}

Differences in matric potential measured over two rainy seasons with replicated tensiometers showed varying trends with depth (Fig. 2). At $0.15 \mathrm{~m}, \mathrm{BC}$-amended plots generally had a slightly lower matric potential (i.e., the soil was relatively drier) than control plots $(-111.8$ vs. $-101.2 \mathrm{hPa}$ on average over all sampling dates, respectively). At $0.3 \mathrm{~m}$, the matric potential was greater (i.e., the soil was relatively more moist) with $\mathrm{BC}$ addition (-90.1 vs. $-101.8 \mathrm{hPa})$, at $0.6 \mathrm{~m}$ it was lower $(-72.2$ vs. $-62.6 \mathrm{hPa})$, and at $2.0 \mathrm{~m}$ it was again greater $(-45.0$ vs. $-52.3 \mathrm{hPa})$. All differences were significant $(p<0.05)$, and no significant differences were found at $1.2 \mathrm{~m}$ depth.

Datalogged tensiometers showed that, at all depths, matric potential was generally slightly lower when BC had been applied than in the absence of $\mathrm{BC}$ application. At the onset of rain events, the soil was drier where $\mathrm{BC}$ had been applied for $81,79,64,93$, and $100 \%$ of rain events observed in 2005 at $0.15,0.3,0.6,1.2$ and $2.0 \mathrm{~m}$ depth, respectively (number of events $=73,67,22,15$, and 13 ; data are shown for a depth of $0.15 \mathrm{~m}$ in Fig. 3). A rise in matric potential of at least $10 \mathrm{hPa}$ at any depth was defined here as a rain event. On the other hand, the greatest matric potential (wetter soil) observed after rain was also greater in the control plot in 45, 84, 86, 93, and $77 \%$ of the rain events recorded in 2005 at $0.15,0.3,0.6,1.2$ and $2.0 \mathrm{~m}$ depths, respectively (Fig. 3). Thus, the measurements of matric potential by tensiometers suggested that the soil was usually slightly drier with $\mathrm{BC}$ application and did not become as wet as the control when it rained.

In contrast, surface soil volumetric water measurements taken when measuring infiltration did not show any signifi- cant differences $(p>0.05)$ (Supplemental Fig. S2), and measurements using datalogged soil water probes installed at $0.3 \mathrm{~m}$ showed that water content was only $3 \%$ greater when $\mathrm{BC}$ had been applied (average from measurements taken in 1-min intervals over a 1 -mo period; $n=27,650$; data not shown).

\section{Modeling Water Flow}

Matric potential output from HYDRUS fit well with values measured using replicated hand-read tensiometers and to a lesser degree with logged tensiometers (Fig. 2). Water flux dominated by unsaturated flow calculated with the model over the 2005 and 2006 rainy seasons was not significantly different between the control and the $\mathrm{BC}$-amended treatments for any depth (differences ranged from 0.2 to $1.4 \%$ ) (Table 4).

\section{Nutrient Leaching}

Biochar application resulted in greater $\mathrm{Ca}$ and $\mathrm{Sr}$ concentrations in soil solution extracted by suction cups at the depths of $0.15,0.3$, and $0.6 \mathrm{~m}$, whereas differences in concentrations of $\mathrm{NH}_{4}, \mathrm{NO}_{3}, \mathrm{~K}$, and $\mathrm{Mg}$ were inconsistent (Table 2). At a depth of $1.2 \mathrm{~m}$, however, $\mathrm{BC}$ applications resulted in consistently lower concentrations $(p<0.05)$ of $\mathrm{Ca}, \mathrm{K}, \mathrm{Mg}, \mathrm{NO}_{3}-\mathrm{N}$, and $\mathrm{Sr}$. At a depth of $2.0 \mathrm{~m}$, solute concentrations were generally one order of magnitude lower than at $1.2 \mathrm{~m}$ depth (except for $\mathrm{P}$ ), and differences between treatments with or without BC additions were inconsistent: Significant concentration reductions $(p<0.05)$ with BC application were observed for K, P, and $\mathrm{NH}_{4}-\mathrm{N}$, whereas $\mathrm{Sr}$ concentrations were significantly greater when $\mathrm{BC}$ was applied $(p<0.05)$. Concentrations in the two treatments generally followed the same trend over time (for $\mathrm{Ca}$ and Sr, see Supplemental Fig. S3). After fertilization events, nutrient concentrations increased at $0.15,0.3$, and $0.6 \mathrm{~m}$ (for $\mathrm{Ca}$ and Sr, see Supplemental Fig. S3).

Amounts of nutrients leached increased from 0.15 to $0.3 \mathrm{~m}$ in some cases and then decreased with depths greater than $0.6 \mathrm{~m}$ (Table 4). Nutrient movement within the main rooting zone $(0-0.6 \mathrm{~m})$ was generally greater when $\mathrm{BC}$ had been applied (Table 4). An exception was P, which at a depth

Table 3. Bulk density, texture, and pH of soil at experimental site and dry density of maize roots with and without biochar additions ( $n=6$ for bulk density; $n=3$ for other data).

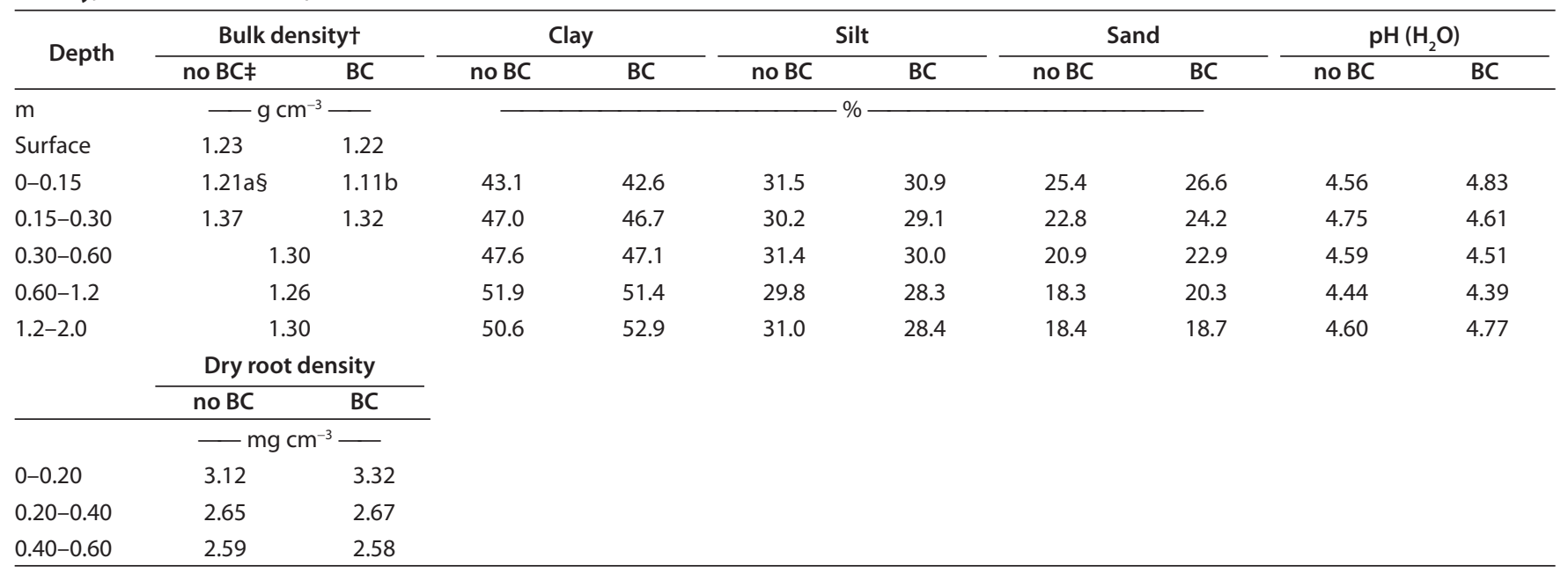

† Value given for the lower depth of increments.

‡ Biochar.

$\S$ Significant differences $(p<0.05)$ between treatments at the same depth are represented by different letters. 


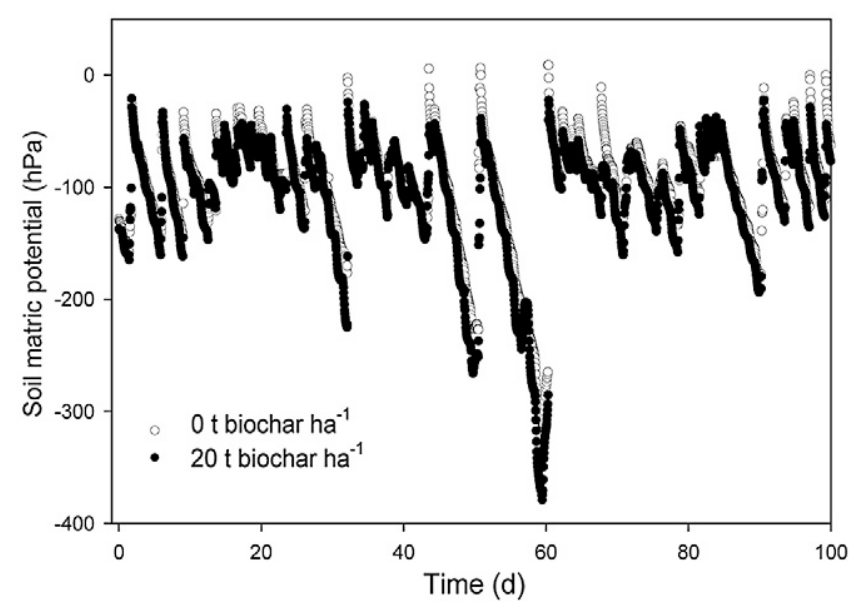

Fig. 3. Soil matric potential for the first $100 \mathrm{~d}$ of the experiment measured by datalogged tensiometers placed at $0.15 \mathrm{~m}$ depth.

of $0.3 \mathrm{~m}$ was leached to a lower extent after BC additions. At a depth of $1.2 \mathrm{~m}$, however, the flux of $\mathrm{Ca}$ was significantly $(p<0.05)$ reduced by $14 \%, \mathrm{Mg}$ by $22 \%, \mathrm{~K}$ by $31 \%, \mathrm{NO}_{3}-\mathrm{N}$ by $2 \%$, and $\mathrm{Sr}$ by $15 \%$ (Table 4 ). At $2 \mathrm{~m}$, nutrient losses were generally one order of magnitude lower than at $1.2 \mathrm{~m}$ depth (with the exception of P), with no clear trend between $\mathrm{BC}$ amendment and control.

\section{Discussion}

\section{Biochar Effects on Soil Physical Properties}

Surface hydraulic conductivity was not significantly affected by $\mathrm{BC}$ additions; this finding was similar to results reported by Laird et al. (2010a). However, the trend for greater conductivity when measured using the ring infiltrometer may indicate greater macroporosity with $\mathrm{BC}$ addition, presumably resulting from better aggregation. Glaser et al. (2004) found that BC-rich anthropogenic dark earths (Terra preta) soils of the Amazon contained 5 to $11 \%$ more macropores $(>50 \mu \mathrm{m})$ than adjacent soils with much lower BC contents. However, these dark earth soils received BC applications hundreds of years ago, thus allowing ample time for aggregation processes to occur through surface interactions of $\mathrm{BC}$ with other soil constituents (Glaser et al., 2000; Liang et al., 2006). In addition, infiltration in the clayey soils studied here (40-44\% clay) may improve not at all or to a lesser degree than in more sandy soils, as shown by Asai et al. (2009). These authors found no difference in surface-saturated hydraulic conductivity of undisturbed soil samples with $48 \%$ clay when $16 \mathrm{t} \mathrm{BC} \mathrm{ha}^{-1}$ had been applied as compared with an unamended control but found a $176 \%$ increase in hydraulic conductivity in soils with only $28 \%$ clay. The amounts of BC added in our study were also not as high as 5 and $10 \%$ by weight, whereas Kameyama et al. (2011) found an increase in saturated hydraulic conductivity after additions of BC made from sugarcane bagasse. At BC application rates of $3 \%$ and below, these authors did not find an effect, similar to our study.

In the studied clay soil, the application of $20 \mathrm{t} \mathrm{ha}^{-1} \mathrm{BC}$ did not produce any significant changes in soil water retention, as also found by Bell and Worall (2011) with an application rate of up to $87.5 \mathrm{t} \mathrm{ha}^{-1}$ to two different soils in the United Kingdom. Tryon (1948) found that a BC application of $15 \%$ by volume to a clay soil even reduced soil water retention by $7 \%$, whereas it was increased in a sandy soil, similar to findings by Uzoma et al. (2011) using BC made from cow manure. Terra preta soils of the Amazon basin originated from well aggregated clay Oxisols and were found to have an 18\% greater field capacity than adjacent soils (Glaser et al., 2004). This was found despite the texture of Terra preta usually being lighter than that of adjacent soil (Teixeira and Martins, 2003). However, Terra preta soils were likely also directly affected by fire and heat, which presumably cause alterations that affect hydrological relations beyond BC enrichment (Teixeira and Martins, 2003). Kameyama et al. (2011) found greater plant-available water in soils that received $\mathrm{BC}$, but large differences existed only at BC concentrations above $3 \%$ by weight, exceeding the amounts in our study. The difference between our results and a study by Laird et al. (2010a), where significant increases in water retention were found with as little as $0.5 \%$ BC addition by weight, are less easily explained and require further research.

\section{Biochar Effects on Water Flux through Soil}

The lack of an effect of BC additions on water flux through soil in our study is not easily explained. Our study did not provide clear evidence for changes in field capacity or infiltration. In contrast, Ayodele et al. (2009) reported significant increases in infiltration of $88 \%$ in soils that received charcoal

Table 4. Nutrients leached over the 2005 and 2006 rainy seasons under a Colombian savanna Oxisol that received 0 or $20 \mathrm{t} \mathrm{ha-1}$ biochar in 2002.

\begin{tabular}{|c|c|c|c|c|c|c|c|c|c|}
\hline \multirow{2}{*}{ Depth } & \multirow{2}{*}{ Biochar } & \multicolumn{8}{|c|}{ Total amounts leached } \\
\hline & & Water & $\mathbf{P}$ & $\mathrm{Sr}$ & $\mathrm{NH}_{4}-\mathrm{N}$ & $\mathrm{NO}_{3}-\mathrm{N}$ & $\mathrm{Ca}$ & $\mathrm{Mg}$ & $\mathrm{K}$ \\
\hline $\mathrm{m}$ & $\mathrm{tha}^{-1}$ & $\mathrm{~mm}$ & $\longrightarrow$ & 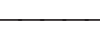 & 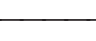 & $-\mathrm{kg} \mathrm{ha}^{-1}$ & & & - \\
\hline \multirow[t]{2}{*}{0.15} & 0 & 2823 & 0.56 & $0.30 \mathrm{~b}+$ & $9.1 \mathrm{~b}$ & 168.9 & $61.2 \mathrm{~b}$ & $42.4 b$ & $206.9 b$ \\
\hline & 20 & 2867 & 0.50 & $0.98 a$ & $69.1 \mathrm{a}$ & 266.4 & $227.7 a$ & $130.3 a$ & $413.6 a$ \\
\hline \multirow[t]{2}{*}{0.3} & 0 & 2742 & $0.44 a$ & $0.57 \mathrm{~b}$ & 2.7 & $234.7 b$ & $125.4 b$ & 84.0 & $190.1 \mathrm{a}$ \\
\hline & 20 & 2750 & $0.38 b$ & $0.87 a$ & 2.2 & $330.9 a$ & $179.3 a$ & 92.0 & $185.9 \mathrm{~b}$ \\
\hline \multirow[t]{2}{*}{0.6} & 0 & 2593 & 0.40 & $0.41 b$ & $1.0 \mathrm{~b}$ & 196.0b & $84.6 \mathrm{~b}$ & $55.5 b$ & $119.5 b$ \\
\hline & 20 & 2588 & 0.36 & $1.00 \mathrm{a}$ & $2.4 a$ & $399.8 a$ & $223.0 a$ & $116.7 a$ & $131.3 a$ \\
\hline \multirow[t]{2}{*}{1.2} & 0 & 2361 & 0.34 & $0.35 a$ & 1.0 & $110.2 \mathrm{a}$ & $54.6 a$ & $33.5 \mathrm{a}$ & $36.0 \mathrm{a}$ \\
\hline & 20 & 2346 & 0.32 & $0.30 \mathrm{~b}$ & 1.6 & $108.1 \mathrm{~b}$ & $47.2 b$ & $26.1 b$ & $24.7 \mathrm{~b}$ \\
\hline \multirow[t]{2}{*}{2.0} & 0 & 2329 & $0.35 a$ & $0.06 \mathrm{~b}$ & $0.6 a$ & 12.7 & $6.5 b$ & 3.1 & 14.9 \\
\hline & 20 & 2296 & $0.26 \mathrm{~b}$ & $0.09 a$ & $0.5 b$ & 19.8 & $9.0 a$ & 4.3 & 13.6 \\
\hline
\end{tabular}

† Different letters represent significant differences $(p<0.05 ; n=3)$ between treatments at a single depth. No letter indicates that differences are not significant (only flux dominated by unsaturated flow). 
from fuel production and minor increases in porosity and decreases in bulk density. However, different BC materials are expected to differ in their ability to improve water relations in different soil types (Novak et al., 2009b), possibly explaining the varying results.

At the observed greater soil volumetric moisture contents with $\mathrm{BC}$, the lower soil water suction could have prevented greater water percolation. Changes in soil water retention properties after $\mathrm{BC}$ addition are less likely to be the reason for the lack of greater water percolation because moisture retention curves did not show a consistent difference between BC treatments. A more likely reason for the observed difference was that greater moisture uptake by larger plants with $\mathrm{BC}$ additions reduced water percolation. Also, Lehmann et al. (2003) observed a reduction in water leached with $\mathrm{BC}$ addition in lysimeter studies with a well aggregated Oxisol and attributed this reduction to greater crop growth and transpiration in the $\mathrm{BC}$-amended soil. Further experimentation is needed to understand these differential effects of $\mathrm{BC}$ on soil water dynamics, recognizing the properties of different $\mathrm{BC}$ materials.

\section{Biochar Effects on Nutrient Leaching}

The increase in nutrient leaching (with the exception of $\mathrm{P}$ ) from the topsoil up to a depth of $0.6 \mathrm{~m}$ was a result of greater soil solution concentrations and not enhanced water flow. The greater solution concentrations of $\mathrm{Ca}$ and $\mathrm{Mg}$ correspond well with the greater amounts of plant-available nutrients found by Major et al. (2010b) in the topsoil of the same experiment. It is not entirely clear from the present assessment of leaching whether the increased plant availability (particularly of $\mathrm{Ca}$ and $\mathrm{Mg}$ near the topsoil), documented by extractable and solution nutrient contents, is a result of retention or greater crop uptake after BC additions (Major et al., 2010b).

In comparison to the topsoil, $\mathrm{BC}$ application reduced the leaching of $\mathrm{Sr}, \mathrm{NO}_{3}-\mathrm{N}, \mathrm{Ca}, \mathrm{Mg}$, and $\mathrm{K}$ immediately below the main rooting zone, which is typically in the first $1 \mathrm{~m}$ for maize (Livesley et al., 2000). At $1.2 \mathrm{~m}$ depth, reductions of $\mathrm{Ca}, \mathrm{Mg}$, and $\mathrm{Sr}$ leached by unsaturated flow after BC additions were similar or greater compared with their increases in plant uptake (determined by Major et al., 2010b), but reductions in inorganic $\mathrm{N}$ and $\mathrm{K}$ leaching were lower than measured increases in plant uptake. These differences between leaching reductions and increase in uptake for some elements may be explained by (i) reductions in leaching during the first $2 \mathrm{yr}$ of the experiment, (ii) the differential uptake by plants at different depths and times that are not sufficiently captured in our study, (iii) other soil nutrient dynamics such as biological $\mathrm{N}$ fixation that may be enhanced by BC (Rondon et al., 2007), or (iv) retention of solutes in the soil. Increases in soil $\mathrm{Ca}, \mathrm{Mg}$, and $\mathrm{Sr}$ availability were also greatest when $\mathrm{BC}$ was applied compared with $\mathrm{N}$ and $\mathrm{K}$ (Major et al., 2010b), which may support the explanation that leaching reductions by $\mathrm{BC}$ were most important in explaining increased plant uptake for $\mathrm{Ca}, \mathrm{Mg}$, and Sr. However, the fact that the leaching reductions were not observed in the topsoil where the $\mathrm{BC}$ was present makes a connection between retention on $\mathrm{BC}$ surfaces and leaching reductions less obvious.

Some evidence supporting the possible retention of Ca and $\mathrm{Mg}$ through $\mathrm{BC}$ amendments, rather than enhanced crop uptake, is the difference in leaching between years (data not shown): The amounts of $\mathrm{Ca}$ and $\mathrm{Mg}$ leached were significantly $(p<0.05)$ greater in 2006 than 2005, whereas yields of maize were significantly $(p<0.001)$ lower in 2006 than in 2005 (Major et al., 2010b). However, the greatest beneficial effect of BC application on yield was observed in 2006, when the reduction of Ca leaching with BC over the control was $299 \%$ greater at $1.2 \mathrm{~m}$ depth $(p<0.05)$ than in 2005.

A retention of solutes has frequently been found after BC additions in lysimeter studies (Lehmann et al., 2003; Novak et al., 2009a; Laird et al., 2010b; Bell and Worall, 2011; Knowles et al., 2011). Lehmann et al. (2003) found a significant delay in $\mathrm{Ca}$ and $\mathrm{Mg}$ leaching when $\mathrm{BC}$ was added to an Oxisol in lysimeter studies cropped to rice, although cumulative reductions were not statistically significant. The largest effect they observed was a reduction in $\mathrm{NH}_{4}-\mathrm{N}$ leaching, which was not the case in our study. Major differences between these two experiments are the type of fertilizer applied, the depth at which leaching was sampled, and the age of the BC. In our study, fertilizer $\mathrm{N}$ was applied as urea, whereas Lehmann et al. (2003) added ammonium sulfate, possibly explaining the pronounced ammonium retention in the cited study. Regarding the lack of $\mathrm{Ca}$ and $\mathrm{Mg}$ leaching reductions in the cited pot study, Lehmann et al. (2003) monitored leaching immediately after the addition of "fresh" BC, and it has been demonstrated that over time BC surfaces become oxidized (Liang et al., 2006; Cheng et al., 2008) and thus are better able to retain positively charged nutrients. In our study, leaching was monitored 3 and $4 \mathrm{yr}$ after the application of $\mathrm{BC}$ to soil, thus allowing time for $\mathrm{BC}$ surfaces to become oxidized and react with other soil constituents. Novak et al. (2009a) also added "fresh" BC to soil and found greater reductions in $\mathrm{Ca}$ and $\mathrm{Mg}$ leaching at $25 \mathrm{~d}$ than at $67 \mathrm{~d}$. This variability may stem from the differences in behaviors of different $\mathrm{BC}$ materials that require further study.

Biochar application also reduced $\mathrm{NO}_{3}-\mathrm{N}$ leaching below the rooting zone. Lehmann et al. (2002) found that wood $\mathrm{BC}$ did not retain $\mathrm{NO}_{3}-\mathrm{N}$ but did retain significant amounts of $\mathrm{NH}_{4}-\mathrm{N}$, using adsorption isotherms. In general, anion exchange capacities of $\mathrm{BCs}$ are low and decrease over time (Cheng et al., 2008), and nitrate adsorption may only be significant with BCs produced at low temperatures (Mishra and Patel, 2009). In contrast, here, $\mathrm{NO}_{3}-\mathrm{N}$ leaching was decreased more than $\mathrm{NH}_{4}-\mathrm{N}$ leaching with $\mathrm{BC}$ addition compared with the unamended control. This may be a result of microbial cycling rather than electrostatic adsorption (Steiner et al., 2008; Laird et al., 2010b; Knowles et al., 2011). Several studies have found greater microbial biomass in BC-amended soil (as reviewed by Lehmann et al., 2011). The retention of pore water containing $\mathrm{NO}_{3}-\mathrm{N}$ observed by Kameyama et al. (2011) may not necessarily have occurred here because the $\mathrm{BC}$ in their study was produced at high pyrolysis temperatures above $700^{\circ} \mathrm{C}$. Nitrate sorption in batch experiments was found with bamboo $\mathrm{BC}$ made at even higher temperatures of $900^{\circ} \mathrm{C}$ (Mizuta et al., 2004).

The alternative explanation to leaching reductions as discussed above may include nutrient uptake as a result of greater crop growth that could be primarily unrelated to nutrient availability. For example, nutrient availability may increase due to $\mathrm{pH}$ increases in acidic soil. Increases in $\mathrm{pH}$ 
values from 4.2 to 5.4 to 5.9 and concomitant decreases in Al toxicity might directly increase plant growth and nutrient uptake after BC addition to low-pH soil (Van Zwieten et al., 2010). However, $\mathrm{pH}$ increases of less than 0.2 units and $\mathrm{Al}$ toxicity reductions were much lower in our study (as outlined by Major et al., 2010b), making this effect not an obvious explanation for our data. Crop nutrient uptake may also increase by improvement of soil water holding capacity or direct nutrient additions through BC (Lehmann et al., 2003). However, water flow did not change after BC additions (Table 4), moisture retention curves were not different (Supplemental Fig. S1), and Major et al. (2010b) reported that direct nutrient additions with $\mathrm{BC}$ were low.

\section{Conclusions}

The application of $20 \mathrm{t} \mathrm{BC} \mathrm{ha}^{-1}$ to a low-fertility, acidic soil of Colombia led to significant increases in concentrations of several nutrients (except $\mathrm{P}$, which was reduced) in soil solution and consequently greater nutrient leaching to a depth of $0.6 \mathrm{~m}$. However, leaching at $1.2 \mathrm{~m}$ was reduced for $\mathrm{NO}_{3}-\mathrm{N}$ by $8 \%$, Ca by $23 \%$, Mg by $28 \%$, and $\mathrm{K}$ by $36 \%$ when compared with the unamended control (differences between treatments at 2.0 $\mathrm{m}$ were low except for $\mathrm{P}$, which was significantly reduced by $\mathrm{BC})$. These changes occurred without relevant changes in net water fluxes. Reductions in $\mathrm{Ca}$ and $\mathrm{Mg}$ leaching at $1.2 \mathrm{~m}$ were larger than crop $\mathrm{Ca}$ and $\mathrm{Mg}$ uptake and occurred with a concomitant increase in $\mathrm{Ca}$ and $\mathrm{Mg}$ availability in soil, suggesting that nutrient retention in the rooting zone may have played a role. However, greater leaching to a depth of $0.6 \mathrm{~m}$ points to the importance of nutrient uptake by crops and the complexity of BC effects on nutrient leaching under field conditions. Further testing is required to determine different BC properties and their value for leaching control in other types of soil and climate, preferably using tracer techniques to distinguish between uptake and retention, and for periods greater than 4 yr. The effect of $\mathrm{BC}$ on soil hydrological properties must be tested in areas where water availability is a limitation for crop productivity, unlike in the work presented here.

\section{Acknowledgments}

We thank Pedro Herrera, Gonzalo Rojas, and Maria del Pilar Hurtado for their friendship and dedicated help in the field. Support for J. Major was provided by a Canada Graduate Scholarship from the Natural Sciences and Engineering Research Council of Canada and by the Saltonstall Fellowship from the Department of Crop and Soil Sciences at Cornell University. Field and laboratory work was supported by grants from Cornell's Center for the Environment, the Bradfield award from Cornell's Department of Crop and Soil Sciences, Cornell's National Science Foundation (NSF)-Integrative Graduate Education and Research Traineeship (IGERT) program, and research travel grants from Cornell's Graduate School. The Centro Internacional de Agricultura Tropical (CIAT) funded the establishment and management of all field operations for this work, with partial support from a USAID linkage grant. We appreciate the helpful comments from the reviewers.

\section{References}

Aberg, G. 1995. The use of natural strontium isotopes as tracers in environmental studies. Water Air Soil Pollut. 79:309-322. doi:10.1007/ BF01100444

Allen, R.G. 2001. RefET (Reference Evapotranspiration Software). Univ. of Idaho, Moscow.
Asai, H., B.K. Samson, S.M. Haefele, K. Songyikhangsuthor, K. Homma, Y. Kiyono, Y. Inoue, T. Shiraiwa, and T. Horie. 2009. Biochar amendment techniques for upland rice production in Northern Laos 1. Soil physical properties, leaf SPAD and grain yield. Field Crops Res. 111:81-84. doi:10.1016/j.fcr.2008.10.008

Ayodele, A., P. Oguntunde, A. Joseph, and M. de Souza Dias. 2009. Numerical analysis of the impact of charcoal production on soil hydrological behavior, runoff response and erosion susceptibility. Rev. Bras. Cienc. Solo 33:137-145. doi:10.1590/S0100-06832009000100015

Bell, M.J., and F. Worall. 2011. Charcoal addition to soils in NE England: A carbon sink with environmental co-benefits? Sci. Total Environ. 409:1704-1714. doi:10.1016/j.scitotenv.2011.01.031

Beven, K., and P. Germann. 1982. Macropores and water flows in soils. Water Resour. Res. 18:1311-1325. doi:10.1029/WR018i005p01311

Blackwell, P., G. Riethmuller, and M. Collins. 2009. Biochar application to soil. p. 207-226. In J. Lehmann, and S. Joseph (ed.) Biochar for Environmental Management: Science and Technology. Earthscan, London.

Boxell, J., and P.J. Drohan. 2009. Surface soil physical and hydrological characteristics in Bromus tectorum L. (cheatgrass) versus Artemisia tridentata Nutt. (big sagebrush) habitat. Geoderma 149:305-311. doi:10.1016/j. geoderma.2008.12.009

Brown, R. 2009. Biochar production technology. p. 127-146. In J. Lehmann and S. Joseph (ed.) Biochar for environmental management: Science and technology. Earthscan, London.

Cahn, M.D., D.R. Bouldin, M.S. Cravo, and W.T. Bowen. 1993. Cation and nitrate leaching in an Oxisol of the Brazilian Amazon. Agron. J. 85:334340. doi:10.2134/agronj1993.00021962008500020032x

Cheng, C.H., J. Lehmann, J.E. Thies, S.D. Burton, and M.H. Engelhard. 2006. Oxidation of black carbon by biotic and abiotic processes. Org. Geochem. 37:1477-1488. doi:10.1016/j.orggeochem.2006.06.022

Cheng, C.H., J. Lehmann, and M. Engelhard. 2008. Natural oxidation of black carbon in soils: Changes in molecular form and surface charge along a climosequence. Geochim. Cosmochim. Acta 72:1598-1610. doi:10.1016/j.gca.2008.01.010

Clescerl, L.S., A.E. Greenberg, and A.D. Eaton (ed.). 1999. Standard methods for the examination of water and wastewater. American Public Health Association, Washington, DC.

Downie, A., A. Crosky, and P. Munroe. 2009. Physical properties of biochar. p. 13-32. In J. Lehmann and S. Joseph (ed.) Biochar for environmental management: Science and technology. Earthscan, London.

Dünisch, O., V.C. Lima, G. Seehann, J. Donath, V.R. Montoia, and T. Schwarz. 2007. Retention properties of wood residues and their potential for soil amelioration. Wood Sci. Technol. 41:169-189. doi:10.1007/ s00226-006-0098-1

FAO. 1983. Simple technologies for charcoal making. FAO Forestry Paper 41, Food and Agriculture Organization of the United Nations, Rome.

Gee, G.W., and J.W. Bauder. 1986. Particle size analysis. p. 383-411. In A. Klute (ed.) Methods of soil analysis, part 1: Physical and mineralogical methods. Agron. Monogr. 9. 2nd ed. ASA, Madison, WI.

Glaser, B., E. Balashov, L. Haumaier, G. Guggenberger, and W. Zech. 2000. Black carbon in density fractions of anthropogenic soils of the Brazilian Amazon region. Org. Geochem. 31:669-678. doi:10.1016/ S0146-6380(00)00044-9

Glaser, B., G. Guggenberger, and W. Zech. 2004. Identifying the pre-Columbian anthropogenic input on present soil properties of Amazonian Dark Earths (Terra Preta). p. 145-158. In B. Glaser and W.I. Woods (ed.) Amazonian dark earths: Explorations in space and time. Springer, Berlin, Heidelberg, New York.

Kameyama, K., T. Miyamoto, T. Shiono, and Y. Shinogi. 2011. Influence of sugarcane bagasse-derived biochar application on nitrate leaching in calcaric dark red soil. J. Environ. Qual., published online. Available at https://www.soils.org/files/publications/jeq/abstracts/biochar/q100453-abstract.pdf (verified 23 Sept. 2011).

Knowles, O.A., B.H. Robinson, A. Contangelo, and L. Clucas. 2011. Biochar for the mitigation of nitrate leaching from soil amended with biosolids. Sci. Total Environ. 409:3206-3210. doi:10.1016/j. scitotenv.2011.05.011

Laird, D.A., P. Fleming, R. Horton, R. Horton, B. Wang, and D.L. Karlen. 2010a. Impact of biochar amendments on the quality of a typical Midwestern agricultural soil. Geoderma 158:443-449. doi:10.1016/j. geoderma.2010.05.013

Laird, D.A., P. Fleming, B. Wang, R. Horton, and D.L. Karlen. 2010b. Biochar impact on nutrient leaching from a Midwestern agricultural soil. Geoderma 158:436-442. doi:10.1016/j.geoderma.2010.05.012

Lehmann, J., J.P. da Silva, Jr., M. Rondon, M.S. Cravo, J. Greenwood, T. Nehls, C. Steiner, and B. Glaser. 2002. Slash-and-char: A feasible alternative 
for soil fertility management in the central Amazon? Paper no. 449. 17th World Congress of Soil Science, Bangkok, Thailand.

Lehmann, J., J.P. da Silva, Jr., C. Steiner, T. Nehls, W. Zech, and B. Glaser. 2003. Nutrient availability and leaching in an archaeological Anthrosol and a Ferralsol of the Central Amazon basin: Fertilizer, manure and charcoal amendments. Plant Soil 249:343-357. doi:10.1023/A:1022833116184

Lehmann, J., M. Rillig, J. Thies, C.A. Masiello, W.C. Hockaday, and D. Crowley. 2011. Biochar effects on soil biota: A review. Soil Biol. Biochem. 43:1812-1836. doi:10.1016/j.soilbio.2011.04.022.

Liang, B., J. Lehmann, D. Solomon, J. Kinyangi, J. Grossman, B. O’Neill, J.O. Skjemstad, J. Thies, F.J. Luizao, J. Petersen, and E.G. Neves. 2006. Black carbon increases cation exchange capacity in soils. Soil Sci. Soc. Am. J. 70:1719-1730. doi:10.2136/sssaj2005.0383

Livesley, S.J., P.J. Gregory, and R.J. Buresh. 2000. Competition in tree row agroforestry systems. 1. Distribution and dynamics of fine root length and biomass. Plant Soil 227:149-161. doi:10.1023/A:1026551616754

Major, J., C. Steiner, A. Downie, and J. Lehmann. 2009. Biochar effects on nutrient leaching. p. 271-288. In J. Lehmann and S. Joseph (ed.) Biochar for environmental management: Science and technology. Earthscan, London.

Major, J., J. Lehmann, M. Rondon, and C. Goodale. 2010a. Fate of soil-applied black carbon: Downward migration, leaching and soil respiration. Glob. Change Biol. 16:1366-1379. doi:10.1111/j.1365-2486.2009.02044.x

Major, J., M. Rondon, D. Molina, S.J. Riha, and J. Lehmann. 2010b. Maize yield and nutrition during four years after biochar application to a Colombian savanna Oxisol. Plant Soil 333:117-128. doi:10.1007/ s11104-010-0327-0

Mehlich, A. 1984. Mehlich-3 soil test extractant: A modification of Mehlich-2 extractant. Commun. Soil Sci. Plant Anal. 15:1409-1416. doi: $10.1080 / 00103628409367568$

Melgar, R.J., T.J. Smyth, P.A. Sanchez, and M.S. Cravo. 1992. Fertilizer nitrogen movement in a Central Amazon Oxisol and Entisol cropped to corn. Fert. Res. 31:241-252. doi:10.1007/BF01063298

Mishra, P.C., and R.K. Patel. 2009. Use of agricultural waste for the removal of nitrate-nitrogen from aqueous medium. J. Environ. Manage. 90:519522. doi:10.1016/j.jenvman.2007.12.003

Mizuta, K., T. Matsumoto, Y. Hatate, K. Nishihara, and T. Nakanishi. 2004. Removal of nitrate-nitrogen from drinking water using bamboo powder charcoal. Bioresour. Technol. 95:255-257. doi:10.1016/j. biortech.2004.02.015

Novak, J.M., W.J. Busscher, D.L. Laird, M. Ahmedna, D.W. Watts, and M.A.S. Niandou. 2009a. Impact of biochar amendment on fertility of a southeastern Coastal Plain soil. Soil Sci. 174:105-112. doi:10.1097/ SS.0b013e3181981d9a

Novak, J.M., I.M. Lima, B. Xing, J.W. Gaskin, C. Steiner, K.C. Das, M. Ahmedna, D. Rehrah, D.W. Watts, W.J. Busscher, and H. Schomberg. 2009b. Charcaterization of designer biochar produced at different temperatures and their effects on a loamy sand. Ann. Environ. Sci. 3:195-206.

Omoti, U., D.O. Ataga, and A.E. Isenmila. 1983. Leaching losses of nutrients in oil palm plantations determined by tension lysimeters. Plant Soil 73:365-376. doi:10.1007/BF02184313

Pietikäinen, J., O. Kiikkila, and H. Fritze. 2000. Charcoal as a habitat for microbes and its effect on the microbial community of the underlying humus. Oikos 89:231-242. doi:10.1034/j.1600-0706.2000.890203.x

Priestley, C.H.B., and R.J. Taylor. 1972. On the assessment of surface heat flux and evaporation using large-scale parameters. Mon. Weather Rev. 100:8192. doi:10.1175/1520-0493(1972)100<0081:OTAOSH>2.3.CO;2

Randall, G.W., D.R. Huggins, M.P. Russelle, D.J. Fuchs, W.W. Nelson, and J.L. Anderson. 1997. Nitrate losses through subsurface tile drainage in conservation reserve program, alfalfa, and row crop systems. J. Environ. Qual. 26:1240-1247. doi:10.2134/jeq1997.00472425002600050007x

Renck, A., and J. Lehmann. 2004. Rapid water flow and transport of inorganic and organic nitrogen in a highly aggregated tropical soil. Soil Sci. 169:330-341. doi:10.1097/01.ss.0000128016.00021.3d

Richards, L.A. 1931. Capillary conduction of liquids through porous media. Physics 1:318-333. doi:10.1063/1.1745010

Rippstein, G., E. Amezquita, G. Escobar, and C. Grollier. 2001. Condiciones naturales de la sabana. p. 1-21. In G. Rippstein et al. (ed.) Agroecologia y biodiversidad de las sabanas en los Llanos Orientales de Colombia. Centro Internacional de Agricultura Tropical (CIAT), Cali, Colombia.

Ritchie, J.T. 1972. Model for predicting evaporation from a row crop with incomplete cover. Water Resour. Res. 8:1204-1213. doi:10.1029/ WR008i005p01204

Rondon, M., J. Lehmann, J. Ramirez, and M. Hurtado. 2007. Biological nitrogen fixation by common beans (Phaseolus vulgaris L.) increases with bio-char additions. Biol. Fertil. Soils 43:699-708. doi:10.1007/ s00374-006-0152-z

SAS Institute. 2003. SAS version 9.1. SAS Inst., Cary, NC.

Senesi, N., M. Polemio, and L. Lorusso. 2005. Evaluation of barium, rubidium and strontium contents in commercial fertilizers. Nutr. Cycling Agroecosyst. 4:135-144.

Sierra, J., C. Noel, L. Dufour, H. Ozier-Lafontaine, C. Welcker, and L. Desfontaines. 2003. Mineral nutrition and growth of tropical maize as affected by soil acidity. Plant Soil 252:215-226. doi:10.1023/A:1024713127053

Šimůnek, J., M. Šejna, H. Saito, M. Sakai, and M.Th. van Genuchten. 2008. The HYDRUS-1D software package for simulating the movement of water, heat, and multiple solutes in variably saturated media, version 4.0. Department of Environmental Sciences, Univ. of California, Riverside.

Sinclair, T.R., J.R. Farias, N. Neumaier, and A.L. Nepomuceno. 2003. Modeling nitrogen accumulation and use by soybean. Field Crops Res. 81:149158. doi:10.1016/S0378-4290(02)00221-6

Singh, B.P., B.J. Hatton, B. Singh, A.L. Cowie, and A. Kathuria. 2010. Influence of biochars on nitrous oxide emission and nitrogen leaching from two contrasting soils. J. Environ. Qual. 39:1224-1235. doi:10.2134/ jeq2009.0138

Soil Survey Staff. 1994. Key to soil taxonomy. Pocahontas Press, Blacksburg, VA.

Smernik, R.J. 2005. A new way to use solid-state carbon-13 nuclear magnetic resonance spectroscopy to study the sorption of organic compounds to soil organic matter. J. Environ. Qual. 34:1194-1204. doi:10.2134/ jeq2004.0371

Steiner, C., W.G. Teixeira, J. Lehmann, T. Nehls, J.L.V. de Macedo, W.E.H. Blum, and W. Zech. 2007. Long term effects of manure, charcoal and mineral fertilization on crop production and fertility on a highly weathered Central Amazonian upland soil. Plant Soil 291:275-290. doi:10.1007/s11104-007-9193-9

Steiner, C., B. Glaser, W.G. Teixeira, J. Lehmann, W.E.H. Blum, and W. Zech. 2008. Nitrogen retention and plant uptake on a highly weathered central Amazonian Ferralsol amended with compost and charcoal. J. Plant Nutr. Soil Sci. 171:893-899. doi:10.1002/jpln.200625199

Teixeira, W.G., and G.C. Martins. 2003. Soil physical characterization. p. 271-286. In J. Lehmann et al. (ed.) Amazonian dark earths: Origins, properties, management. Kluwer, Dordrecht, the Netherlands.

Tomasella, J., and M.G. Hodnett. 1998. Estimating soil water retention characteristics from limited data in Brazilian Amazonia. Soil Sci. 163:190202. doi:10.1097/00010694-199803000-00003

Tryon, E.H. 1948. Effect of charcoal on certain physical, chemical, and biological properties of soils. Ecol. Monogr. 18:81-115. doi:10.2307/1948629

Uzoma, K.C., M. Inoue, H. Andry, H. Fujimaki, A. Zahoor, and E. Nishihara. 2011. Effect of cow manure biochar on maize productivity under sandy soil condition. Soil Use Manage., published online. Available at https:// www.soils.org/files/publications/jeq/abstracts/biochar/q10-0453-abstract.pdf (verified 23 Sept. 2011).

van der Ploeg, R.R., and F. Beese. 1977. Model calculations for the extraction of soil water by ceramic cups and plates. Soil Sci. Soc. Am. J. 41:466470. doi:10.2136/sssaj1977.03615995004100030007x

Van Zwieten, L., S. Kimber, S. Morris, K.Y. Chan, A. Downie, J. Rust, S. Joseph, and A. Cowie. 2010. Effects of biochar from slow pyrolysis of papermill waste on agronomic performance and soil fertility. Plant Soil 327:235-246. doi:10.1007/s11104-009-0050-x

Warnock, D.D., J. Lehmann, T.W. Kuyper, and M.C. Rillig. 2007. Mycorrhizal responses to biochar in soil: Concepts and mechanisms. Plant Soil 300:9-20. doi:10.1007/s11104-007-9391-5

Yu, X.Y., G.G. Ying, and R.S. Kookana. 2006. Sorption and desorption behaviors of diuron in soils amended with charcoal. J. Agric. Food Chem. 54:8545-8550. doi:10.1021/jf061354y 